ISSN 1392-3196 / e-ISSN 2335-8947

Zemdirbyste-Agriculture, vol. 101, No. 4 (2014), p. 419-424

DOI $10.13080 /$ z-a.2014.101.053

\title{
The peculiarities of genetic structure of the Blumeria graminis f. sp. hordei population in Lithuania
}

\author{
Inese KOKINA ${ }^{1}$, Grazina STATKEVICIUTE ${ }^{2}$, Alge LEISTRUMAITE ${ }^{2}$, Isaak RASHAL ${ }^{3}$ \\ ${ }^{1}$ Institute of Systematic Biology, Daugavpils University \\ Vienības 13, Daugavpils, Latvia \\ E-mail: inese.kokina@biology.lv \\ ${ }^{2}$ Institute of Agriculture, Lithuanian Research Centre for Agriculture and Forestry \\ Instituto 1, Akademija, Kèdainiai distr., Lithuania \\ ${ }^{3}$ Institute of Biology, University of Latvia \\ Miera 3, Salaspils, Latvia
}

\begin{abstract}
In 2010, samples of Blumeria graminis $\mathrm{f}$. sp. hordei both in sporulation and cleistothecia were collected in Lithuania from spring barley variety 'Dina'. Eighty monopustule isolates were tested on differentials with well-known resistance genes. Frequencies of virulence genes, virulence complexity and pathotypes were detected. Virulence frequencies showed a wide range from 0 to $90 \%$. The clear tendency of virulence increasing for Vla in cleistothecia was observed during the growing season of the pathogen. No virulences were found against resistances, which were present in the line $S I 1$, as well as no matching virulence was found for the resistance gene mlo in Lithuania in 2010. Wide diversity of the population is confirmed by the present of high number of detected pathotypes. In the samples in sporulation, the pathotype $a 6$ a 7 a 9 al2 $\mathrm{k}$ la was the most abundant and the dominant pathotype in cleistothecia was a 7 a $912 \mathrm{k}$ la. In comparison with 2000, significant changes in virulence genes frequencies, complexity and pathotypes were detected in 2010 .
\end{abstract}

Key words: barley, Blumeria graminis f. sp. hordei, complexity, pathotype, resistance, virulence.

\section{Introduction}

Powdery mildew fungi are parasites that cause disease on a wide range of important crops. The grass powdery mildew fungus is classified into eight formae speciales (ff. spp.) based on the strict host specialization (Wyand, Brown, 2003). Barley powdery mildew caused by Blumeria graminis f. sp. hordei is one of the most devastating diseases (Naghavi et al., 2007), which can cause serious yield losses. The pathogen is a wind-borne and obligate biotrophic pathogen, often used as a model in understanding host-parasite interaction (Dreiseitl, Wang, 2007). The disease can be controlled easily with fungicides, but it may represent a serious threat for barley produced in low input and organic agriculture (Dreiseitl et al., 2006; Kokina, Rashal, 2008). Genetic resistance is an effective, economically sound and safe alternative to fungicide application (Dreiseitl, 2008). Plant resistance $(R)$ genes, which induce host defenses against powdery mildews, encode proteins that recognize avirulence (AVR) molecules from the parasite in a gene-for-gene manner (Skamnioti et al., 2008). Partial resistance is characterized by a compatible interaction in all growth stages, but a lower frequency of infection, a longer latent period, or lower rate or shorter period of a spore production (Jørgensen, 1994).

The evolutionary potential of a pathogen population is reflected in its population genetic structure. Pathogen populations with a high evolutionary potential are more likely to overcome genetic resistance than pathogen populations with a low evolutionary potential (McDonald, Linde, 2002). Recombinations and efficient dispersal contribute high adaptation potential for Blumeria graminis f. sp. hordei. Airborne migration of spores also favours the spread of new genotypes, which can travel over large distances (Limpert, 1987). A high level of pathogenic variability in local populations has been demonstrated in many studies (Limpert, 1987; Czembor, 2010; Kokina, Rashal, 2012).

Agricultural land constitutes $53 \%$ of the total area in Lithuania. Among cereals, spring barley is the second most widely grown crop after winter wheat. Winter barley hardly survives Lithuanian winters; in 2010 it comprised only about $6 \%$ of the total barley area (Statistical Yearbook of Lithuania, 2011). Some investigations have been done on the field resistance of spring barley varieties to powdery mildew in Lithuania, 
when Lithuania-registered genotypes, new genotypes for initial breeding and genotypes from collections of genetic resources were tested (Liatukas, Leistrumaite, 2007). The recent study concerning genetic peculiarities of the population of the causal agent of barley powdery mildew in Lithuania was done in 2000 (Kokina, Rashal, 2002). The overall goal of this study was to evaluate virulence frequencies, distribution of virulence genes, dominant pathotypes and their complexity in the population of Blumeria graminis f. sp. hordei from Lithuania in 2010.

\section{Material and methods}

Eighty isolates of powdery mildew causal agent Blumeria graminis f. sp. hordei, used in this study, were collected from the spring barley variety 'Dina' in Lithuania in 2010 both in sporulation and cleistothecia. Sampling size and dates are presented in Table 1.

Table 1. Sampling date and number of pathogen samples collected in Lithuania in 2010

\begin{tabular}{ccc}
\hline Sampling date & $\begin{array}{c}\text { Phase of the } \\
\text { pathogen }\end{array}$ & $\begin{array}{c}\text { Number of } \\
\text { isolates }\end{array}$ \\
\hline 13 July & conidia & 40 \\
4 August & cleistothecia & 40 \\
\hline
\end{tabular}

Samples of barley leaves with well-developed vegetative sporulation or cleistothecia were used. Collected conidia spores were settled on detached healthy and fully-expanded primary leaves of the susceptible barley variety 'Otra'. Samples of cleistothecia were stored at a temperature of $4-8^{\circ} \mathrm{C}$. Isolates were purified by single colony isolation. The standard set of differentials was used for testing single colonies (Table 2).

Table 2. Set of differentials used for detection of virulence genes in powdery mildew causal agent Blumeria graminis f. sp. hordei samples collected in Lithuania in 2010

\begin{tabular}{cc}
\hline Differentials & Main resistance genes \\
\hline$P 01$ & Mla1 \\
$P 02$ & Mla3 \\
$P 03$ & Mla6 \\
$P 04 B$ & Mla7 \\
$P 08 B$ & Mla9 \\
$P 10$ & Mla12 \\
$P 11$ & Mla13 \\
$P 17$ & Mlk \\
$P 23$ & MlLa \\
SI1 & Ml(SI) \\
'Steffi' & Ml(St1), Ml(St2) \\
'Goldie' & Mla12, MlLa, U \\
'Meltan' & Mla13, Ml(Im9), Ml(Hu4) \\
\hline
\end{tabular}

Each differential was grown in the laboratory conditions at $24^{\circ} \mathrm{C}$, photoperiod $10 \mathrm{~h}$ for $12-14$ days and for further inoculation the central part of healthy primary leaves was used. Leaf segments of each differential, approximately $25 \mathrm{~mm}$ long, were placed on the $0.7 \%$ water agar with 35 ppm benzimidazole (Dreiseitl, 2004). For inoculation of the leaf segments the microinoculation technique was used (Dreiseitl, 1998). Conidia from each single isolate were shaken onto differentials. Incubation of inoculated segments of differentials was carried out under $18-20^{\circ} \mathrm{C}$ in light with a photoperiod of $10 \mathrm{~h}$. After 7-10 days of incubation, the disease reaction types of differentials were scored according to a 0-4 scale (Jørgensen, 1994). For type of infection, characterized by segregated colonies originating from the stomatal cells and expressed when the gene mlo is present, symbol 0(4) (i.e. infection type 0 with a few colonies corresponding to infection type 4) was used. Isolates that produced infection type 0-3 were considered as avirulent on the corresponding differentials. Infection type 4 only was defined as virulent on the corresponding differentials. Virulence frequency, complexity (virulence gene number per genotype) and pathotypes or combinations of virulence genes in genotypes were calculated. Statistical significance of differences between virulence frequencies was evaluated using the Student $t$-test at $\alpha=0.05$.

\section{Results and discussion}

In 2010, 80 monopustule isolates were obtained for study of the Lithuanian population of Blumeria graminis f. sp. hordei. Virulence frequencies of $\mathrm{Val}$, $\mathrm{Va} 3$ and $\mathrm{Val} 3 \mathrm{were}$ middle and varied from $35 \%$ to $42.5 \%$ and from $37.5 \%$ to $47.5 \%$ in sporulation and cleistothecia, respectively (Fig. 1).

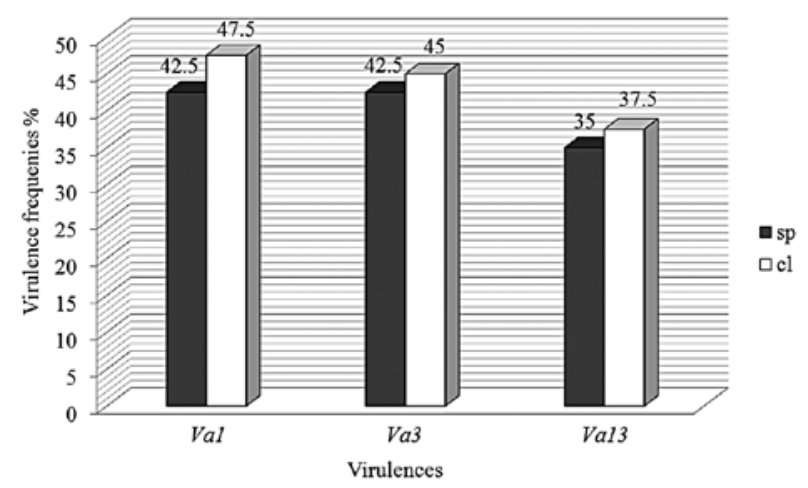

Figure 1. Virulence frequencies of Va1, Va3 and Val3 in sporulation ( $\mathrm{sp}$ ) and cleistothecia (cl) phases in Lithuania in 2010

Some increasing of virulences mentioned above in cleistothecia was detected. The virulence frequency detected on the Va6, Va7, Va9, Va12, Vk and VLa ranged from $60 \%$ to $90 \%$ (Fig. 2). The clear tendency of virulence increasing for $\mathrm{Vla}$ from $70 \%$ in sporulation to $90 \%$ in cleistothecia was observed during growing season of the pathogen.

The virulence frequency detected on the varieties 'Steffi', 'Goldie' and 'Meltan' ranged from 15\% to $25 \%$ (Fig. 3 ).

All differencies among virulences in sporulation and cleistothecia were statistically significant, except 


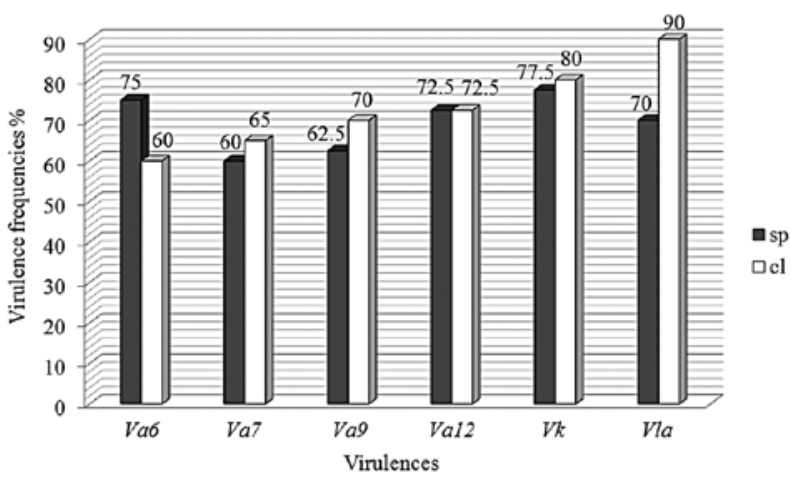

Figure 2. Virulence frequencies of $\mathrm{Va} 6, \mathrm{Va} 7, \mathrm{Va} 9, \mathrm{Va} 12$, $V k$ and $V L a$ in sporulation (sp) and cleistothecia $(\mathrm{cl})$ phases in Lithuania in 2010

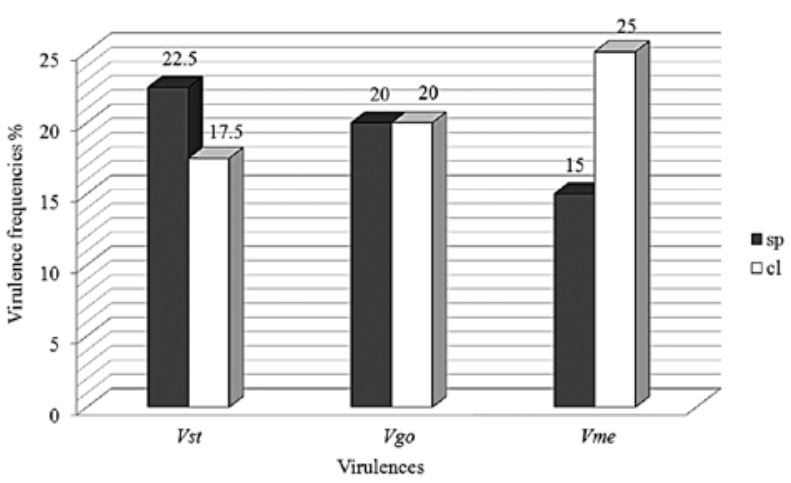

Figure 3. Virulence frequencies of Vst, Vgo and Vme in sporulation ( $\mathrm{sp}$ ) and cleistothecia $(\mathrm{cl})$ phases in Lithuania in 2010

for Va12 (Table 2) and Vgo (Table 3). In contrast, no virulences were found against resistances, which were present in the line SII.

Long-term changes in virulence in Blumeria graminis f. sp. hordei in Lithuania in 2010 can be examined by comparing current results with the data obtained in 2000 (Kokina, Rashal, 2002). In 2010, we found considerably higher frequency of virulences for resistance genes Mla1, Mla3 and Mla13 common in European barley varieties. One of the main reasons for considerable increasing of correponding virulences $\mathrm{Val}$, Va3 and Va13 during last 10 years in Lithuania could be explained by propagation of the pathogen spores according to the main wind direction with an average speed of $110 \mathrm{~km}$ per year (Limpert, 1987). During the recent years, a clear tendency to higher frequencies of the virulences Val, Va3 and Val3 in Europe was observed (Dreiseitl et al., 2006; Dreiseitl, 2008), including Latvia (Kokina, Rashal, 2008). Consequently, data observed in 2010 showed that the corresponding resistance genes Mla1, Mla3 and Mla13 lost their effectiveness in Lithuania as well.

In comparison with 2000, in 2010 some decreasing of virulences $\mathrm{Va} 6, \mathrm{Va} 7, \mathrm{Va} 9$ and $\mathrm{Va} 12$ was detected in Lithuania. The virulence frequency for $V k$ practically did not change. In contrast, Vla frequency was markedly higher, especially in phase of cleistothecia. Overall, high virulences of genes mentioned above proved ineffectiveness of the corresponding resistance genes Mla6, Mla 7, Mla8, Mla9, Mla12, Mlk and Mlla in Lithuania at the moment like in other populations of the pathogen in Europe (Hovmøller et al., 2000; Dreiseitl et al., 2006; Kokina, Rashal, 2008).

During last ten years, virulence frequency of $V m e$ considerably increased from $6.6 \%$ in 2000 to $25 \%$ in cleistothecia in 2010. The corresponding resistance of the variety 'Meltan', which in fact is controlled by three genes (Mla13, $\mathrm{Ml}(\operatorname{Im} 9), \mathrm{Ml}(\mathrm{Hu} 4)$ ) is still effective. Based on the data obtained, further increasing of the virulence $V m e$ in the pathogen population can be forecast. Similar tendency to considerable increasing during last decade was observed for $V s t$ and $V g o$ from $1.3-2.6 \%$ in 2000 to approximately $20 \%$ in 2010 . In the $20^{\text {th }}$ century, approximately 40 alleles for race-specific resistance to powdery mildew, either alone or in combination, have been used in Europe. Resistance genes Mla6, Mla7, Mla9, Mla12 and Mla13 belonging to the Mla locus and the resistance alleles $M l k, M l g, M l L a, M l h$ and Mlra have been used in approximately 700 varieties (Jørgensen, 1994). All these genes are gradually overcome by virulent races within four to five years when varieties containing them are grown on a large acreage (Wolfe, McDermott, 1994). This occurs because the causal agent of barley powdery mildew is able to develop new genotypes which rapidly spread across Europe on susceptible barley varieties.

In 2010, no matching virulence was found for the resistance gene $m l o$ in Lithuania. Barley mlo resistance has remained highly effective since 1979, when commercial spring barley varieties with the resistance were first released. Currently, this resistance is the most used resistance in spring barley grown throughout Europe (Lyngkjær et al., 2000; Kokina et al., 2008). Some surveys pointed out that isolates that appeared virulent on mlo in the virulence test could not be propagated on barley line with mlo. The apparent virulence of these isolates may have been to some environmental factors causing breakdown of the resistance in some of the differentials plants with mlo (Dreiseitl et al., 2006; Makepeace et al., 2007).

Identification of new sources of resistance to barley powdery mildew is important in relation to disease resistance management. Barley line SI1 with unknown resistance genes, which is defined as a new source of resistance (Hovmøller et al., 2000), was also included in the set of differentials. In 2010, not any isolate of the pathogen from Lithuanian population break down resistance factors from $S I 1$.

Wide diversity of the population is confirmed by the present results by the high number of detected pathotypes. In 2010, 26 pathotypes in sporulation and 21 pathotypes in cleistothecia were found (Table 3). In samples in sporulation the pathotype a6 a7 a9 al2 $k$ la was the most abundant $(25.0 \%)$. The mentioned pathotype was present in the samples from cleistothecia too, but with considerably lower frequency $(12.5 \%)$. The dominant pathotype in cleistothecia was a 7 a9 a12 $\mathrm{k}$ la 
with the frequency $15 \%$. This pathotype was not present in sporulation at all, likewise pathotypes a6 a7 a9 a12 a13 $\mathrm{k} l a$ and $a 1$ a $39 \mathrm{k} l a$. The pathotype al a3 a6 a7 a9 a12 a13 k la st go me which overcomes resistances of 12 out of 13 differentials occurs in cleistothecia only with considerable frequency $(7.5 \%)$ in the population. Pathotypes al a3 a6 a7 a9 a12 a13 $k$ and a3 a6 a12 la st were present in sporulation only with frequencies $10 \%$ and $5 \%$, respectively. A significant finding is a new pathotype al a3 a13 which appeared both in sporulation $(5.0 \%)$ and cleistothecia (7.5\%) and which was not detected in 2000 in Lithuania (Kokina, Rashal, 2002). The mentioned pathotype was also detected in Latvia (first time in 2001) with considerable frequencies (till 7\%) (Kokina, Rashal, 2004).

Table 3. Dominant pathotypes and their frequencies in the pathogen population in sporulation and cleistothecia phases in Lithuania in 2010

\begin{tabular}{|c|c|c|}
\hline \multirow[b]{2}{*}{ Dominant pathotypes } & \multicolumn{2}{|c|}{ Frequencies \% } \\
\hline & $\begin{array}{c}\text { sporulation } \\
\text { phase }\end{array}$ & $\begin{array}{c}\text { cleistothecia } \\
\text { phase }\end{array}$ \\
\hline a 6 a 7 a9 a $12 \mathrm{k} l a$ & 25.0 & 12.5 \\
\hline al a3 a6 a 7 a9 a 12 a $13 \mathrm{k}$ & 10.0 & - \\
\hline a1 a3 a13 & 5.0 & 7.5 \\
\hline a3 a6 a12 la st & 5.0 & - \\
\hline a 7 a9 a $12 \mathrm{k}$ la & - & 15.0 \\
\hline a6 a 7 a9 a 12 a $13 \mathrm{k}$ la & - & 7.5 \\
\hline al a3 a9 k la & - & 7.5 \\
\hline al a3 a6 a 7 a9 a 12 a 13 k la st go me & - & 7.5 \\
\hline Total number of pathotypes & 26 & 21 \\
\hline Mean complexity & 5.95 & 6.30 \\
\hline
\end{tabular}

Note. Pathotypes were calculated for virulence genes $\mathrm{Val}, \mathrm{Va} 3$, Va6, Va7, Va9, Va12, Va13, Vk, VLa, VSI, VSt, VGo and VMe; "-" - pathotype was not present in corresponding phase.

Most of the popular spring barley varieties grown in Lithuania carry mlo gene, therefore they exhibit full resistance to powdery mildew. However, variety 'Beatrix' carrying other than mlo resistance genes is also available on the market. It has $M l g, M l(C P), M l L a$, Mla12, Mla17 resistance genes. Variety 'Beatrix' has been registered in the National Variety List since 2007 (Lithuanian National List of Plant Varieties, 2011), and it exhibited a high resistance to powdery mildew in variety trials, carried out by State Plant Service in 2005-2006, but in recent years distributing companies have recommend fungicide spray for disease control.

The adaptation of the pathogen population in Lithuania, like in others (Dreiseitl et al., 2006; Kokina, Rashal, 2008) also resulted in huge increase in its virulence complexity against corresponding resistance genes. The maximal detected complexity was 8 in 2000 (Rashal et al., 2000) and 12 in 2010 (Fig. 4). The mean isolate complexity was approximately 6 virulences per genotype with none considerable changes in sporulation and cleistothecia.

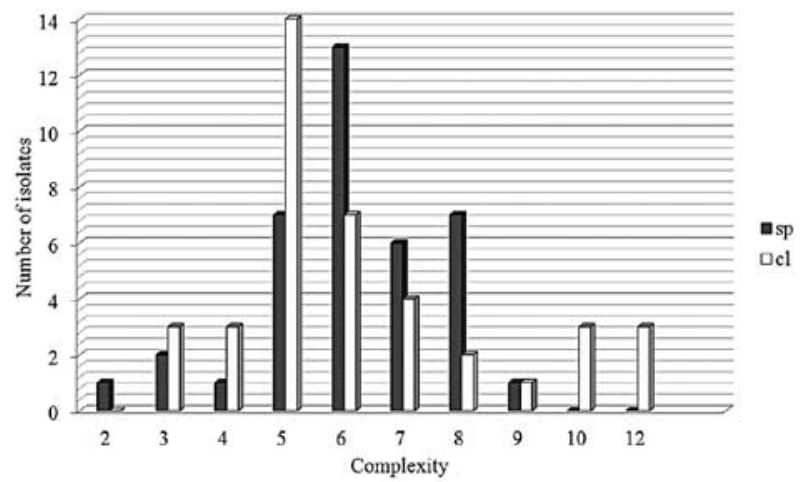

Figure 4. Distribution of virulence complexity in the population of powder mildew causal agent Blumeria graminis f. sp. hordei in sporulation ( $\mathrm{sp}$ ) and cleistothecia (cl) phases in Lithuania in 2010

This study revealed the ability of Blumeria graminis f. sp. hordei to adapt and produce new pathotypes with high complexity. Based on the increasing isolate complexity over the last decade in Lithuania, it can be assumed that individual use of new resistance genes in new varieties will lead to quick overcoming of its resistance. Pyramiding of resistance genes is advisable for success. On the other hand, further long-term investigations of the pathogen evolution are necessary.

\section{Conclusions}

1. Barley powdery mildew resistance genes Mla1, Mla3 and Mla13 have lost their effectiveness in Lithuania.

2. High frequences of virulences genes Va6, $\mathrm{Va}$, Va8, Va9, Val2, Vk and Vla in Lithuanian population of powder mildew causal agent Blumeria graminis $\mathrm{f}$. sp. hordei proved ineffectiveness of the corresponding barley resistance genes Mla6, Mla 7, Mla8, Mla9, Mla12, Mlk and Mlla.

3. Increasing of the virulence complexity in Lithuanian population of Blumeria graminis f. sp. hordei was detected in 2010 in comparison with 2000.

4. In 2010, in Lithuania no matching virulence was found for the barley powdery mildew resistance gene $m l o$, as well as no virulences were found against resistances, which are present in the line $S I 1$.

Received 20122013 Accepted 16052014

\section{References}

Czembor J. Z. 2010. Resistance to powdery mildew in barley (Hordeum vulgare L.) landraces from Egypt. PGR Newsletter, 123: 52-60

Dreiseitl A. 1998. Comparison of methods to study powdery mildew and monitor the population of Erysiphe graminis $\mathrm{f}$. sp. hordei in 1997. Plant Protection Science, 34: 33-38

Dreiseitl A. 2004. Virulence frequencies to powdery mildew resistance genes of winter barley cultivars. Plant Protection Science, 40 (4): 135-140 
Dreiseitl A. 2008. Virulence frequency to powdery mildew resistance in winter barley cultivars. Czech Journal of Genetics and Plant Breeding, 44 (4): 160-166

Dreiseitl A., Wang J. 2007. Virulence and diversity of Blumeria graminis f. sp. hordei in East China. European Journal of Plant Pathology, 117: 357-368 http://dx.doi.org/10.1007/s10658-007-9104-1

Dreiseitl A., Dinoor A., Kosman E. 2006. Virulence and diversity of Blumeria graminis f. sp. hordei in Israel and in the Czech Republic. Plant Disease, 90: 1031-1038 http://dx.doi.org/10.1094/PD-90-1031

Hovmøller M. S., Caffier V., Jalli M., Andersen O., Besenhofer G., Czembor J. H., Dreiseitl A., Felsenstein F., Fleck A., Heinrics F., Jonsson R., Limpert E., Mercer P., Plesnik S., Rashal I., Skinnes H., Slater S., Vronska O. 2000. The European barley powdery mildew virulence survey and disease nursery in 1993-1999. Agronomie, 20 (7): 729-743 http://dx.doi.org/10.1051/agro:2000172

Jørgensen J. H. 1994. Genetics of powdery mildew resistance in barley. Critical Reviews in Plant Sciences, 13: 97-119 http://dx.doi.org/10.1080/07352689409701910

Kokina I., Rashal I. 2002. Genetic structure peculiarities of the Blumeria graminis f. sp. hordei population in the northeastern part of Lithuania. Biologija, 3: 47-49

Kokina I., Rashal I. 2004. Genetical structure of the population of Blumeria graminis f. sp. hordei in Latgale region of Latvia in 2001-2002. Acta Biologica Universitatis Daugavpiliensis, 4 (2): 65-70

Kokina I., Rashal I. 2008. Results of the monitoring of the population of Blumeria graminis f. sp. hordei in the Latgale region of Latvia in 2007. Zemdirbyste-Agriculture, 95 (3): $320-326$

Kokina I., Rashal I. 2012. Results of monitoring of the population of Blumeria graminis f. sp. hordei in Latvia in 2009-2010. Proceedings of the Latvian Academy of Sciences. Section B, 66 (1-2): 41-47

Kokina A., Legzdina L., Berzina I., Bleidere M., Rashal I., Rostok N. 2008. Molecular marker-based characterization of barley powdery mildew Mlo resistance locus in European varieties and breeding lines. Latvian Journal of Agronomy, 11: 77-82

Liatukas Ž., Leistrumaitė A. 2007. Field resistance of spring barley cultivars to powdery mildew in Lithuania. Biologia, 62 (6): 664-669

http://dx.doi.org/10.2478/s11756-007-0132-2

Limpert E. 1987. Barley mildew in Europe: evidence of wind dispersal of the pathogen and its implication for improved use of host resistance and of fungicides for mildew control. Wolfe M. S., Limpert E. (eds). Integrated control of cereal mildews: monitoring the pathogen, p. 31-33

Lithuanian National List of Plant Varieties 2011. <http://www. vatzum.lt/lt/veikla/veiklos-sritys/augalu-veisles/\#Veisli\% C5\%B3_s\%C4\%85ra\%C5\%A1ai> [accessed 2110 2013]

Lyngkjær M. F., Newton A. C., Atzema J. L., Baker S. J. 2000. The barley mlo-gene: an important powdery mildew resistance source. Agronomie, 20: 745-756 http://dx.doi.org/10.1051/agro:2000173

Makepeace J. S., Oxley S. J. P., Havis N. D., Hackett R., Burke J. I., Brown J. K. M. 2007. Associations between fungal and abiotic leaf spotting and the presence of $m l o$ alleles in barley. Plant Pathology, 56: 934-942 http://dx.doi.org/10.1111/j.1365-3059.2007.01680.x
McDonald B., Linde C. 2002. Pathogen population genetics, evolutionary potential and durable resistance. Annual Review of Phytopathology, 40: 349-379 http://dx.doi.org/10.1146/annurev.phyto.40.120501.101443

Naghavi M.-R., Mohammadi V., Ghannadha M.-R. 2007. Gene number and heredity of barley powdery mildew (Erysiphe graminis f. sp. hordei) resistance at adult plant stage. International Journal of Agriculture and Biology, 9 (2): 239-241

Rashal I., Araja I.,Kokina I. 2000. Barley powdery mildew virulence and corresponding resistance in the Baltic States. A. Bender (ed.). Plant breeding and seed production. VIII. Collaboration on Plant Breeding in the Baltic Sea Region. Jõgeva Plant Breeding Institute, p. 96-100

Skamnioti P., Pedersen C., Al-Chaarani G. R., Holefors A., Thordal-Christensen H., Brown J. K., Ridout C. J. 2008. Genetics of avirulence genes in Blumeria graminis $\mathrm{f}$. sp. hordei and physical mapping of $A V R_{\mathrm{a} 22}$ and $A V R_{\mathrm{a} 12}$. Fungal Genetics and Biology, 45 (3): 243-252 http://dx.doi.org/10.1016/j.fgb.2007.09.011

Statistical Yearbook of Lithuania 2011. <http://www.stat.gov. lt/lt/catalog/list/?cat_y=1\&cat_id=1\&id=1944> [accessed $21102013]$

Wolfe M. S., McDermott J. M. 1994. Population genetics of plant pathogen interactions: the example of the Erysiphe graminis-Hordeum vulgare pathosystem. Annual Review of Phytopathology, 32: 89-113 http://dx.doi.org/10.1146/annurev.py.32.090194.000513

Wyand R. A., Brown J. K. M. 2003. Genetic and forma specialis diversity in Blumeria graminis of cereals and its implications for host-pathogen co-evolution. Molecular Plant Pathology, 4 (3): 187-198 http://dx.doi.org/10.1046/j.1364-3703.2003.00167.x 
ISSN 1392-3196 / e-ISSN 2335-8947

Zemdirbyste-Agriculture, vol. 101, No. 4 (2014), p. 419-424

DOI $10.13080 / \mathrm{z}-\mathrm{a} .2014 .101 .053$

\title{
Miltligès sukẻlẻjo (Blumeria graminis f. sp. hordei) Lietuvos populiacijos genetinès struktūros ypatybès
}

\author{
I. Kokina ${ }^{1}$, G. Statkevičiūtè ${ }^{2}$, A. Leistrumaité2 I. Rashal $^{3}$ \\ ${ }^{1}$ Daugpilio universiteto Sisteminès biologijos institutas, Latvija \\ ${ }^{2}$ Lietuvos agrarinių ir miškų mokslų centro Žemdirbystès institutas \\ ${ }^{3}$ Latvijos universiteto Biologijos institutas
}

\section{Santrauka}

Miltligès sukèlèjo Blumeria graminis f. sp. hordei grybienos su konidijomis ir kleistotecių èminiai buvo surinkti Lietuvoje 2010 m. nuo veislès 'Dina' vasarinių miežių. Aštuoniasdešimties monoizoliatų virulentiškumas įvertintas naudojant diferencinį miežių rinkinị su gerai žinomais atsparumo genais ir nustatyti virulentiškumo genų dažniai, virulentiškumo kompleksiškumas bei patotipai. Virulentiškumo dažniai svyravo nuo 0 iki 90 \%. Pastebėta ryški Vla virulentiškumo didejjimo tendencija kleistoteciuose. $2010 \mathrm{~m}$. Lietuvoje nenustatytas virulentiškumas atsparumo genams, esantiems vasarinių miežių linijoje SI1, taip pat nerasta virulentiškumas mlo atsparumo genui. Miltligès populiacijos genetinės ịvairovès aukštą lygị patvirtino didelis kiekis nustatytų patotipų. Dažniausiai pasitaikantis patotipas micelio su sporomis ėminiuose buvo a6 a7 a9 a12 k la, o kleistoteciuose dominavo a7 a9 al2 $\mathrm{k}$ la patotipas. Lyginant su 2000 m., 2010 m. nustatyti reikšmingi virulentiškumo genų dažnių, kompleksiškumo ir patotipų pokyčiai.

Reikšminiai žodžiai: atsparumas, Blumeria graminis f. sp. hordei, kompleksiškumas, miežiai, patotipas, virulentiškumas. 